\title{
BioTechniques
}

\section{Join us for the Advancing Precision Medicine BioTechniques Online Symposium}

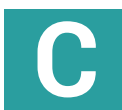

onferences are great for learning about the latest research in the field and for networking, but everyone has at some point wished they were back in the comfort of their own home/lab. You can have the best of both worlds with our upcoming online event!

On 13 and 14 November this year, we'll be holding a free-to-attend virtual conference on advancing precision medicine - and you're invited.

We're currently building an exciting program, and have some excellent experts presenting - including Stephanie Devaney (All of Us), Rob Knight (UCSD), Elaine Mardis (OSUCCC) and Heidi Rehm (Broad).

So, join us, our experts and sponsors to learn about the latest tech and

66 ....we'll be holding a free-to-attend virtual conference on advancing precision medicine - and you're invited.'

techniques in precision medicine, covering genomics, cell models, translational research, host-pathogen/environment interactions and more.

Can't attend the whole event? No problem! Registrants can check back later and watch on demand.

Find out more and register for free at: http://bit.ly/PrecMed2019

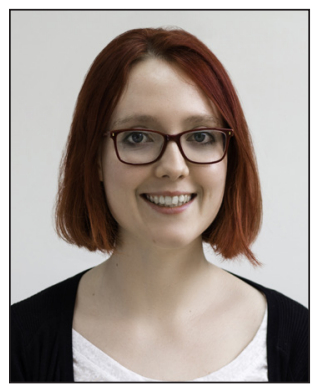

\section{Francesca Lake}

Head of Open Access Publishing, Future Science Group, Unitec House, 2 Albert Place, London, UK. f.lake@future-science.com

\section{BioTechniques Staff}

\section{Editorial, Production \& Circulation}

Chairman: James Drake

Managing Director. Phil Garner

Head of Open Access: Francesca Lake

Managing Editor. Joseph Martin

Digital Editor: Abigail Sawyer

Head of Production: Zara Robinson

\section{Sales \& Business Offices}

Advertising: JT Hroncich • jt@biotechniques.com

Subscriptions: Dominik March•d.march@future-science.com

Reprints: Sam Cavana • s.cavana@future-science.com

List Rental: Leela Ripton • I.ripton@future-science.com

Permissions: Adriana Gonzalez • a.gonzalez@future-science.com

\section{Editorial Board}

Bill Brizzard, Indiana University Research and

Technology Corp.

Bruce Budowle, UNT Health Science Center

Piotr Chomczynski, Molecular Research Center

Rita R. Colwell, University of Maryland-College Park and Johns Hopkins University

Joshua J. Coon, University of Wisconsin-Madison

David Cronk, Charles River Laboratories

Manel Esteller, Spanish National Cancer Centre (CNIO)

Jeffrey Felton, Western University of Health Sciences

Erica A. Golemis, Fox Chase Cancer Center

Peter M. Gresshoff, The University of Queensland

Yoshihide Hayashizaki, RIKEN

Jörg Hoheisel, German Cancer Research Center

Pui-Yan Kwok, University of California, San Francisco

Rachael L. Neve, Massachusetts Institute of Technology

Peter J. Oefner, University of Regensburg

Stephen W. Paddock, University of Wisconsin-Madison

Scott D. Patterson, Gilead Sciences, Inc.

Leonard F. Peruski, Jr., Centers for Disease Control

George Poste, Arizona State University

John Quackenbush, Harvard School of Public Health

Joshua Rappoport, Northwestern University School of Medicine

John Rossi, City of Hope

Michel Goedert, MRC

Herbert P. Schweizer, Colorado State University

Barton Slatko, New England Biolabs

Steve S. Sommer, MEDomics, LLC

Igor Stagljar, University of Toronto

Mathias Uhlén, The Royal Institute of Technology

Timothy Veenstra, SAIC-Frederick, Inc.

Kent E. Vrana, Penn State College of Medicine

Michael Weiner, AxioMx
BioTechniques is a peer-reviewed journal dedicated to the publication of original laboratory methods, related technical tools, and methods-oriented review articles that are of broad interest to scientists engaged in basic applied life science research. Complete Instructions for Authors are available at: https://mc04.manuscriptcentral. $\mathrm{com} / \mathrm{fs}$-btn, BioTechniques' website for online manuscript submission. All manuscripts should be submitted at this site. 